DOI: 10.22616/REEP.2019.017

\title{
The Attitudes of Estonian Crafts Teachers on the Completion of the Crafts Syllabus and the Factors Influencing the Completion of the Syllabus
}

\author{
Aron Lips ${ }^{1} \mathrm{MA}$; Andry Kikkull ${ }^{2} \mathrm{PhD}$ \\ Tallinn University, Estonia \\ aronlips@tlu.ee'; andryk@tlu.ee ${ }^{2}$
}

\begin{abstract}
A study on the study literature on Estonian crafts lessons was carried out in 2018 which revealed that study literature on crafts has not been updated simultaneously with the development of the crafts syllabus and that newer literature has been published only for covering new topics. Therefore, crafts teachers have no other option than to use study literature from different time periods and additional sources to carry out the learning process and to complete the syllabus. Besides the study literature and the syllabus which serves as the source document for the studies, several other factors also support the conduction of the studies. This article is based on the study carried out in 2018, investigating the attitudes of crafts teachers on the valid syllabus of crafts and the use of the possibilities to support the learning motivation of the students when completing the syllabus. Moreover, the impact of the physical learning environment of crafts lessons on the completion of the syllabus and the conduction of the learning process was studied. The aim of this article is to describe and account for the attitudes of Estonian crafts teachers in the light of the above studies. A web-based questionnaire was used in the study, which allowed to collect as much study materials as possible within a short period of time. The data was processed with Statistical Package for the Social Sciences (SPSS 25) software. The results indicated that the teachers complete the crafts syllabus only selectively and partially, mostly according to their own beliefs and the possibilities offered by the school. When carrying out the learning activities in crafts lessons, the teachers mainly consider the interests of the students and attempt to support the creation of their learning motivation and positive attitudes towards the subject. The physical learning environment also varies by schools, however, in most cases it does not serve as an important obstacle for the completion of the syllabus.
\end{abstract}

Keywords: craft and technology education, school education, crafts syllabus, teachers' attitudes.

\section{Introduction}

The source document for the learning process in schools is the national curriculum which determines the educational standard and contains the syllabi of different subjects (National curriculum for..., 2014). It can be assumed that crafts teachers mainly use the crafts syllabus as the basis for their work. The studies also reveal that for different reasons (own beliefs, physical learning environment), the teachers tend to deviate from the content of the crafts syllabus (Kikkull, 2016; Riismaa, 2017). A.V. Kelly (2004) has outlined the different definitions describing the curriculum: complete, hidden, planned and received curriculum. According to A.V. Kelly, the complete curriculum characterises the extent of planned studies. The planned curriculum is related to direct learning activities and the received curriculum characterises the learning activities that have been carried out. (Kelly, 2004) However, the hidden curriculum characterises the purposeful learning of things that are not in the text of the curriculum or occur due to the interpretation of the curriculum by the teacher. The wide occurrence of the hidden curriculum among the Estonian crafts teachers has been outlined by the study by A. Kikkull (2018), which indicated that the main learning objective of the teachers did not originate from the crafts syllabus, instead, the teachers taught their own beliefs and experiences. Additionally, the difference also lies in whether the curriculum only reflects clear educational activities or deliberately unconscious activities which lead to hidden learning. For instance, the personal example of a teacher as the source of unconscious learning. In conclusion, it can be said that despite the unambiguously written curriculum, it can still be interpreted differently by different teachers and is therefore individual (Schwartz, 2006).

The teacher is the one who designs the learning environment and can therefore influence the behaviour of the students by promoting the desired ways of behaviour, however, the teacher can also help to value the learning opportunities - the inner motivation and the need for self-realisation give the learning process a new meaning and value (Brophy, 2010). Consequences do not motivate activities that are intrinsically motivated, the only necessary "reward" is the interest and satisfaction experienced when doing these activities. The typical self-determined behaviour is an internally motivated activity that we 
take on because of our own will. According to the self-determination theory, the social environment supports the intrinsic motivation, if it fulfils the three natural psychological needs: autonomy (deciding on your own what to do and how to do it), competence (obtaining skills related to the management and control of the environment and implementation of those skills) and relatedness (the feeling of togetherness through proportional relationships) (Brophy, 2010). Hence, the students experience intrinsic motivation in the environment which helps them to satisfy the need for autonomy, competence and relatedness. These, however, are important instruments for teachers for building a student-centred learning environment in crafts lessons. Nowadays, such personalised learning is more and more supported by the syllabus of crafts - Technology (Subject field syllabi..., 2014). If there is no support, the students perceive control instead of the opportunity for self-realisation, therefore, their motivation is mostly extrinsic rather than intrinsic (Deci, Ryan, 1985, 2002).

Starting with the year 2018, the implementation of Competence-based Curriculum has to be started also in Latvia. The new model of education aims at developing students' competences which means knowledge, understanding, skills, abilities and attitudes. More than 17003 teachers from 80 Latvian educational institutions are going to be involved in the approbation of new curriculum which affects all school subjects, including Home Economics and Technologies. The goal of education is to prepare students for real life and successful career in future. They need not only to acquire the knowledge and skills but also to develop the ability to use their knowledge effectively and responsibly. This means that the role and tasks of teachers are also changing (Pridane, 2017).

People mostly experience the state of flow when they are absorbed in an activity that fascinates them but is also sufficiently challenging at the same time. For the state of flow situation, students usually prefer such situations where the presented problem corresponds to the level of the skills they have. This is valid for all situations where students undertake activities voluntarily and know that the quality of their performance does not have compelling consequences. If for important reasons they have to solve the task effectively, then they will probably prefer situations where their skills outrank the problem. Although we consider the experience of the flow valuable when being absorbed in the activity, we also want to experience satisfaction from the efficient termination of the activity (Brophy, 2010). M. Csikszentmihalyi, K. Rathunde and S. Whalen (1993) say that teachers can promote the creation of the state of flow in three ways. For this, you need the following:

- know your subject well, teach it with passion and serve as an example as a human being;

- maintain optimal balance between the prescribed requirements and the goals that the students are capable of achieving (demand the achievement of high but reasonable goals while helping them);

- offer the students guidance and emotional support, so that they could perform their learning tasks confidently and without anxiety.

Perfect teachers have intrinsic motivation to both learn and teach their subject and they serve as examples to their students (Csikszentmihalyi, 1993; Csikszentmihalyi, 1997). With their enthusiasm, they encourage the students to value this subject and enjoy studying it. At school, anxiety is the factor that most threatens the potential flow status. If students are constantly asked to perform tasks that exceed their skills, they may start preferring the safe monotony instead of potential flow statuses hiding in challenges. Finally, their potential to experience the status of flow in classroom disappears for good. An insufficient challenge may also be the problem: the students admit the lack of interest in lessons where the requirements are clearly below the level of their knowledge and skills (Turner et al., 1998). Therefore, the tasks given in crafts lessons should be with the sufficient level of difficulty and differentiated based on students.

At the same time, achieving constant intrinsic motivation as a goal when planning daily studies and different motivation strategies is not realistic because studying at school requires the achievement of extrinsically established learning outcomes from students, whereas the activity is compulsory and the performance is graded (Brophy, 2010).

Besides the requirements of the syllabus and the motivation of students, the activities of teachers are also influenced by very many other factors, one of which in teaching crafts is the physical learning environment. According to the available knowledge, the impact of the physical learning environment on the completion of the syllabus has not been extensively studied as regards to crafts lessons. At the same time, the physical learning environment and the used materials set considerable limits to the 
teaching of crafts (Soobik, 2013). For successful learning, the learning environment of crafts must offer opportunities for both the teaching of suitable content as well as allowing students to obtain knowledge when implementing and testing the acquired knowledge (Ritz, Moye, 2011; Parikka, Rasinen, 2009) bring out that as regards to crafts lessons, the physical learning environment where the students are active and work, has one of the most important roles. This is because the workshop is the place where the students are offered the material-technical basis that is needed for their practical work.

The aim of this article is to describe and account for the attitudes of Estonian crafts teachers in the light of the above studies.

\section{Methodology}

This article is based on the opinion survey of the Estonian crafts teachers, conducted in the 2018. The following research questions were set to study the subject:

- What are the attitudes of teachers as regards to the completion of the syllabus?

- How do teachers consider the different abilities and learning motivation of the students when completing the syllabus?

- Whether and how does the physical learning environment affect the completion of the syllabus?

A web-based questionnaire was used to find answers to the research questions. This form of questionnaire was used because within a relatively short period of time and without the researcher being physically present, web-based questionnaires allow to receive structured data which is half ready for data processing (Wilson, McLean, 1994). GoogleForm environment was used to conduct the survey. The questionnaire was forwarded to all the teachers teaching technology education in Estonia (357 respondents). The questionnaire contained 12 free answer or multiple-choice questions, whereas the time spent for the completion of the questionnaire was about 10 minutes. The questions were divided into five categories: the background data of the respondents, the syllabus and its content, the capacity and motivation of students, the physical learning environment and learning materials. Eighty-three filled out questionnaires were returned. The questionnaire provided data belonging to different type identifiers, which were analysed with program SPSS 25 , allowing to present different necessary statistics.

\section{Results and Discussion}

Background data of respondents. The background data of the responded teachers allows to compare them with the general data of the teachers and determine whether the responded teachers represent the section of the general sample or deviate from that (Cohen, Manion, Morrison, 2007). At the same time, the background data allows to compare different teacher groups with each other and find differences and similarities between the groups, and to generally characterise the crafts teachers.

Ninety-four percent of the responded teachers were male and $6 \%$ female, which represents the general gender-based distribution of the Estonian crafts teachers (Craft teachers' data..., 2017). The average age of the teachers was 49 years, which represents the general average age of Estonian teachers, which was 47.9 years in 2013. Seventy-four percent of the responded teachers were over 40 and $26 \%$ were under 40 , which indicates the averagely older age of the Estonian crafts teachers and allows to presume that the teachers currently working have acquired their professional education many years ago. At the same time, $60 \%$ of all the responded crafts teachers have higher education, which allows to presume the averagely higher awareness of the subject.

Syllabus and its content. The curriculum of the school and the related syllabus are certainly the most important documents regulating the subject. In Estonia, the national curriculum and the syllabi are developed and updated regularly in approximately every 4 to 6 years. Therefore, in order to complete the syllabus, it is essential to know and read this essential document that serves as the basis for the studies. Based on that, the teachers were asked when the last time they read the syllabus of crafts was. The positive thing is that at least $94 \%$ of the teachers have read the valid syllabus (Figure 1), however, the attitude of the rest of the $6 \%$ of teachers is worrying, since they have not got acquainted with the valid syllabus.

Hence, it may be concluded that teachers are aware of the syllabus and the learning objectives regardless of what kind of learning they carry out in their lessons. Therefore, it can be assumed that teachers are 
interested in the content of the syllabus and the requirements established for the subject. However, this alone does not ensure the automatic adherence to the syllabus.

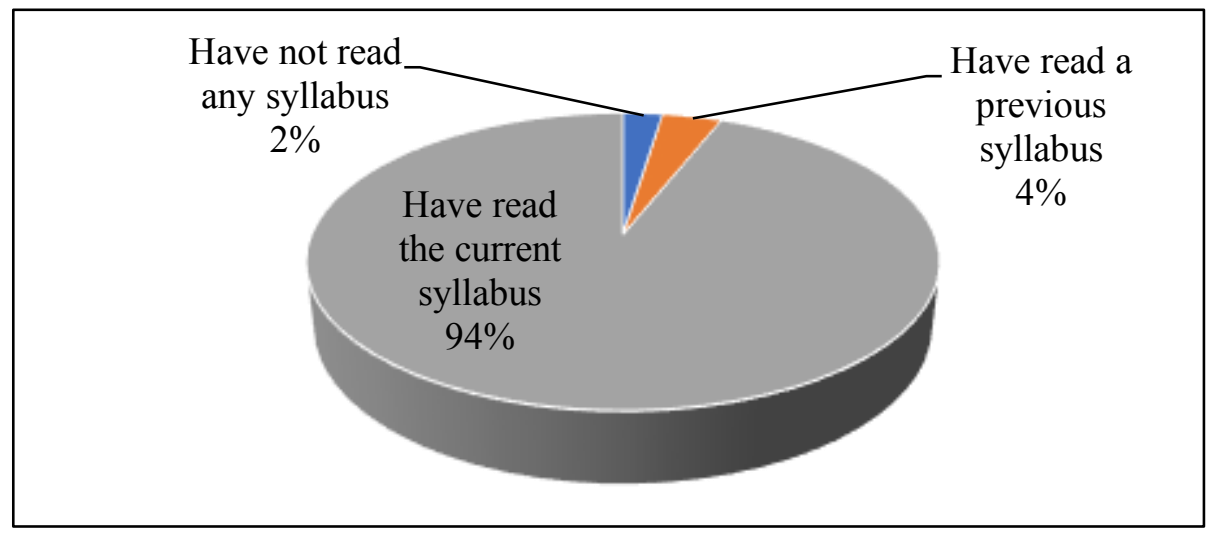

Figure 1. Teachers who have read the syllabus.

For this purpose, the questionnaire investigated the general opinion of the crafts teachers of the syllabus, the importance thereof and the usability of it when carrying out the learning activities. Figure 2 outlines the results. The answers indicate that $39 \%$ of the teachers consider the syllabus as an important guidance material for the studies and adhere to it to a greater or smaller extent. However, $25 \%$ of the teachers do not consider the syllabus important and they teach at their own discretion, and $36 \%$ of the teachers consider the syllabus too complex to understand it properly. Therefore, it can be generalised that $61 \%$ of the teachers do not consider the valid syllabus of crafts important as the basis for their teaching process or finds it too complicated. The overload problem of the national curriculum in Estonia is also referred to in the study conducted by P. Viirpalu, E. Krull and R. Mikser (2014).

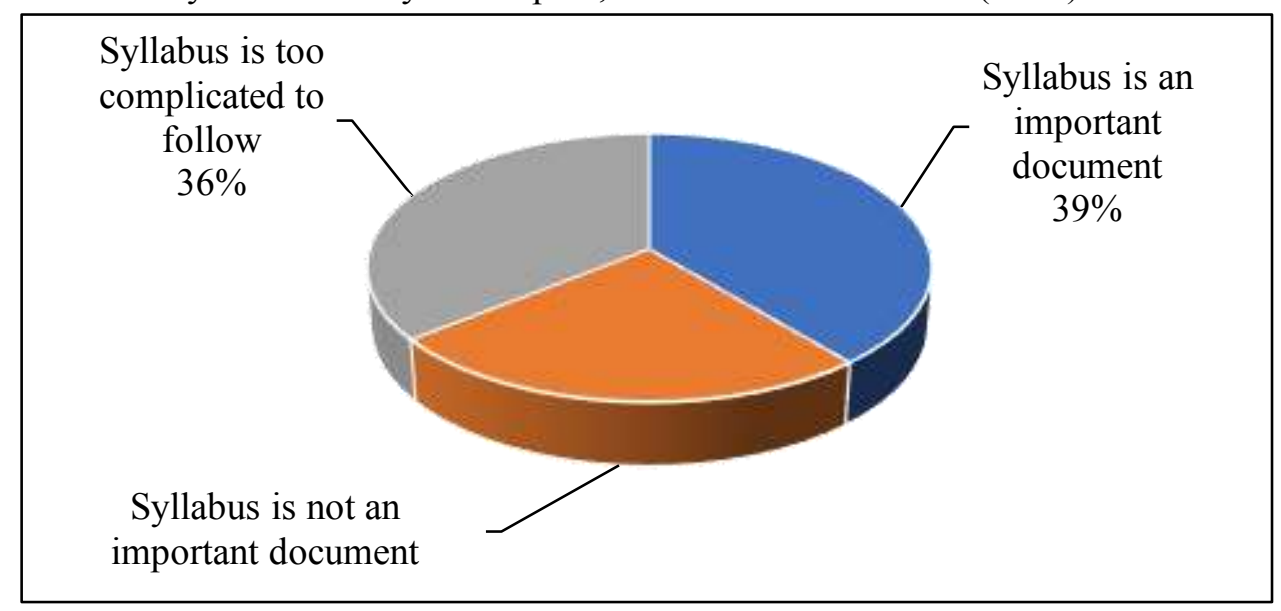

Figure 2. The opinion of the teachers of the syllabus of technology education.

The teachers have also outlined different reasons which prevent them from completing the syllabus. The shortcomings of the syllabus are: difficult to understand, difficult use of language, too general and therefore does not outline specific topics and tools, and the lack of explanatory materials. This situation also allows to presume that teachers are not satisfied with the valid syllabus and that it needs to be developed further and made clear to the teachers. $81 \%$ of the respondents also support this position (Figure 3), admitting that they only partially consider it important to execute the content of the syllabus.

Dissatisfaction with the valid national curriculum and misunderstandings regarding the completion thereof may be due to the latest development and updating of the Estonian national curriculum for basic schools (Viirpalu, Krull, Mikser, 2014). Throughout times, the main form for achieving the learning objectives of crafts lessons has been independent practical work with materials and tools (Borg, 2006). The previously valid crafts syllabus also outlined that in crafts lessons, practical activities should cover approximately $2 / 3$ of the learning time. It was not necessary to adhere to such ratio in every lesson. When handling a new work method or topic, the majority of the lesson was spent on theory issues or work techniques. However, in lessons where labour-intensive items were prepared, the best part of the lesson was dedicated to practical work (National curriculum for..., 2002). 


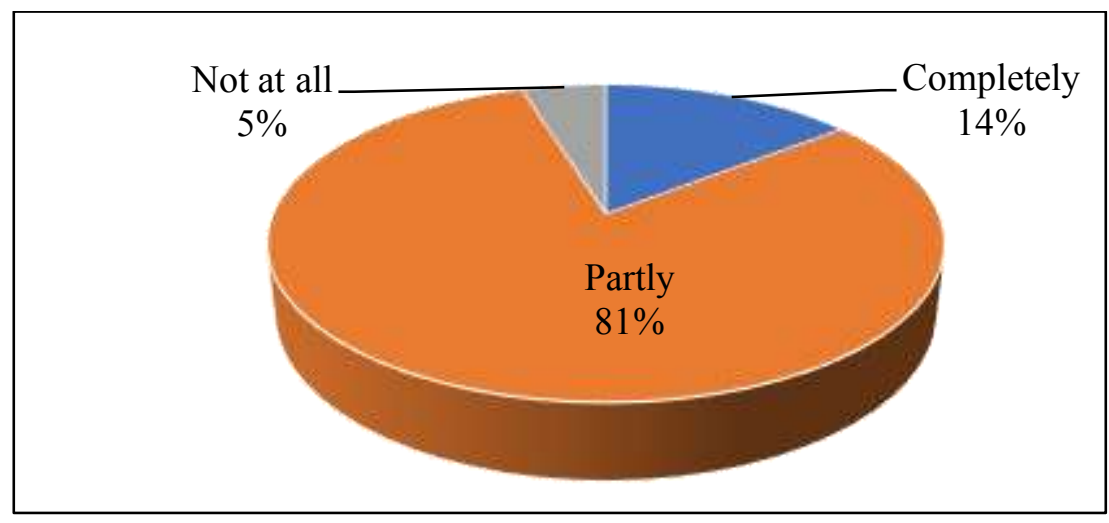

Figure 3. When planning the studies, I consider it important to complete the content of the syllabus.

The new and still valid syllabus for technology education adopted in 2011 did not, however, foresee similar volume of practical learning activities and stressing the importance of different technology related study topics, it divided the studies in technology education into five parts: technology in everyday life; design and drafting; processing of materials; homemaking; project work. The first three parts take up approximately $65 \%$ of the studies, homemaking $10 \%$ and project work $25 \%$ (Subject field syllabi..., 2014).

Based on this information, the teachers were asked which objects of the syllabus they consider important in the crafts syllabus. The answers revealed that teachers consider it equally important to obtain both technological literacy, incl. development of technology related knowledge and skills, and to feel satisfaction of the practical self-realisation as well as obtaining knowledge and skills, handling different materials, tools and ways of processing, which were highlighted 50 times. In principle, teachers confirm the position that in Estonian crafts lessons, practical work skills and satisfaction from the performed practical activities continue to play an important role. This was followed by creativity and design, which was noted 42 times.

To sum up, the main point to outline is that teachers are aware of the learning objectives of the syllabus but if there is a clash between their own beliefs of teaching the subject and the syllabus, then teachers mainly rely on their own values and not the guiding role of the syllabus. Teachers care about the traditional values of the subject, which have lasted for decades, and the newest learning objectives of the syllabus, which are based on technology education, are not rooted that easily.

Capacity and motivation of students. Students have different knowledge and skills and they have different capacity to perform the tasks. Therefore, for successful teaching, teachers cannot always use unvaried teaching methods and are forced to differentiate and vary the study process. Based on that, it was investigated whether the teachers perceive the differences in completing the syllabus when teaching students with different capacities. It occurred that $78 \%$ of the teachers perceives or partially perceives the influence of students with different capacities when completing the syllabus (Figure 4).

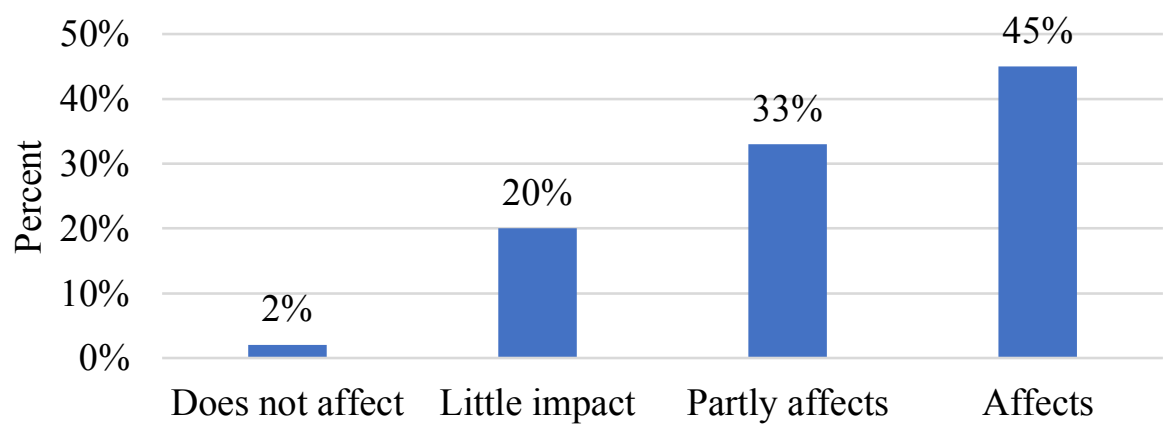

Figure 4. Influence of the capacity of students.

They bring out that depending on the level of difficulty of the studies, the students have different receptivity and that different students cannot achieve the learning outcomes foreseen in the syllabus at an equal level. The latter, however, is largely a subjective assessment for the learning outcomes of the syllabus because the syllabus describes the learning outcomes at a sufficiently general level and allows to differentiate the studies based on the capacity of the students. The attempt of $45 \%$ of the teachers to 
take all students to one level is therefore not justified with the syllabus and it originates from the learning objectives they have set on their own.

The different capacity of students makes the teacher differentiate the study work and use the intrinsic motivation of the students to increase their learning efficiency, encouraging them to study and work (Kikkull, 2016). At school, students should learn how to conceptualise, visualise and materialise their ideas and needs, learn how to take risks, dare to make mistakes and learn how to express themselves through practical work (Hargreaves, 2003). This, however, cannot happen without the sufficient intrinsic motivation and determination of the student. Therefore, from the position of the completion of the syllabus, it is important to investigate, whether teachers use the personal interest and intrinsic motivation of the students for the completion of the syllabus (Figure 5).

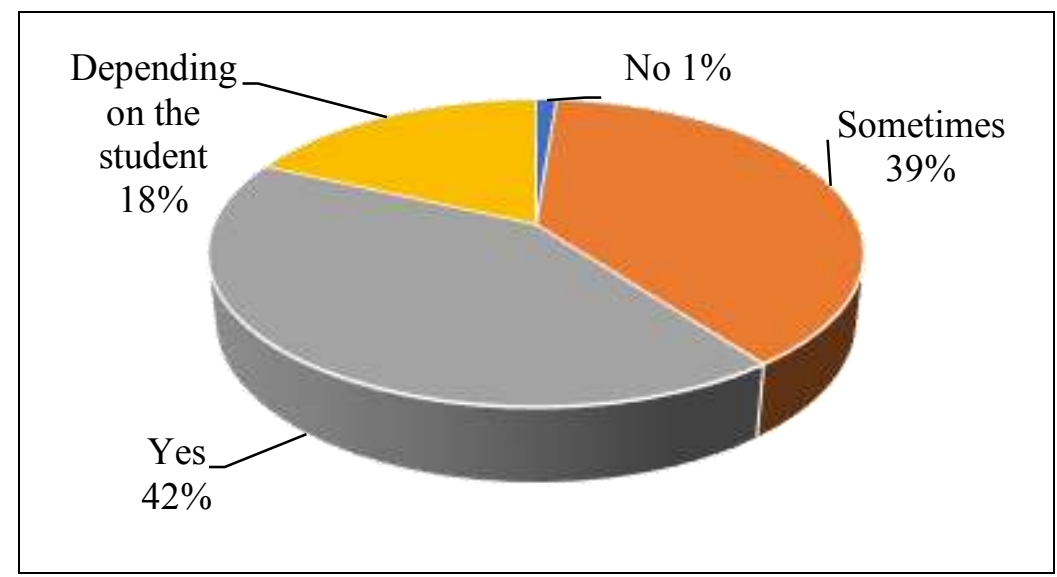

Figure 5. Taking into consideration the different interests of students.

The answers revealed that virtually all teachers have used this opportunity in their work. $18 \%$ of the teachers uses the personal interests of students based on the students. This is probably the more active share of the students whose interests in crafts lesson prevail the most. $64 \%$ of the respondents provided an answer to the free answer question asking how do they do it. The most popular option (21 respondents) was the greater freedom of choice given to students: the opportunity to come up with a suitable design for their work or the preparation technology, which can also be connected with describing the guidelines of the syllabus of crafts and the learning outcomes with increased level of generalisation. These are the so-called personalised works which allow the students to be more involved in the work process (Kikkull, 2016). Besides that, the teachers considered it important to take the interests of students into consideration (17) and to differentiate the tasks given to students (15). It can be concluded that since the crafts syllabus does not directly determine the work objects or techniques, it gives the crafts teachers in Estonia an unlimited opportunity to differentiate the studies. Nevertheless, not all teachers are capable of implementing it well (Kikkull, 2018). This can be seen in the answers of the teachers regarding the syllabus, where $28 \%$ of the responded teachers wished that the syllabus would describe the topics and types of work in more detail.

Physical learning environment and materials. Besides the syllabus and the students in the classroom, the physical learning environment is another factor that has an impact on the completion of the syllabus by the teacher (Riismaa, 2017). The teachers were asked if the available physical learning environment limits the completion of the syllabus.

Twenty-seven percent of the teachers answered that the physical learning environment allows to fully conduct the studies according to the syllabus (Figure 6). The improvement of physical learning environments is the result of the renovation of schools during the past decade, which has included the renovation of the workshops in schools (Soobik, 2013). At the same time, 62\% of the teachers have problems with the physical learning environment and it prevents them from properly completing the syllabus, and $12 \%$ of the teachers work in inappropriate conditions for teaching crafts. The most problematic are the deficient or obsolete tools and lack of space. Both factors considerably restrict the conduction of the studies in larger groups of students. 


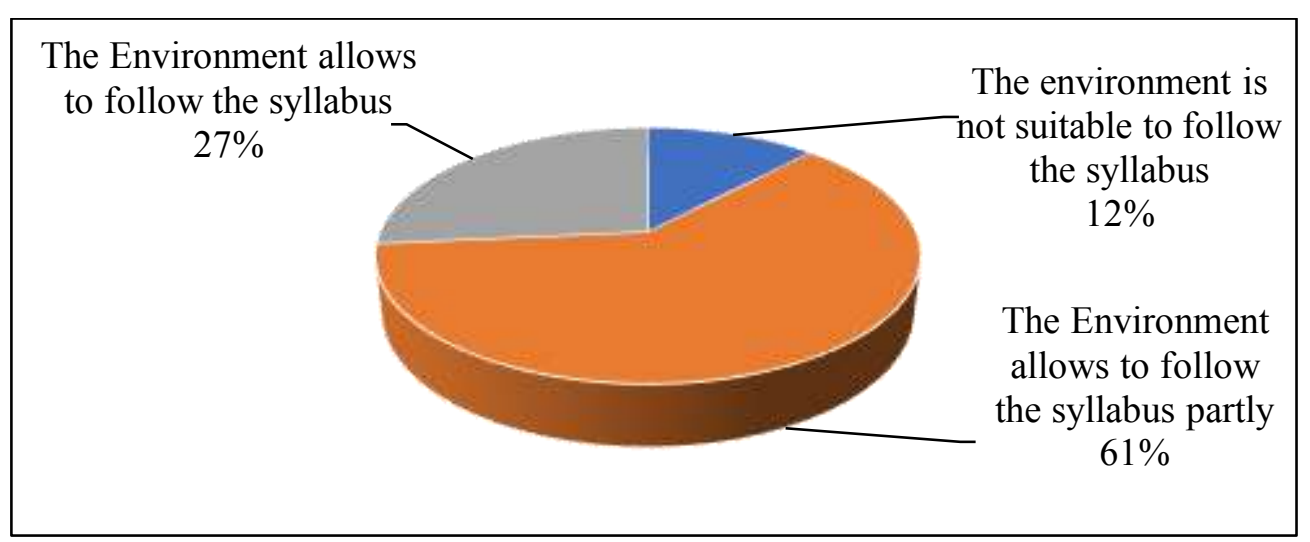

Figure 6. Suitability of the physical learning environment for the completion of the syllabus.

It can be concluded that the learning environment the teacher works in does not considerably influence their attitudes towards the completion of the curriculum. For instance, teachers who work in both good as well as poor physical learning environment have the same attitude towards the full completion of the syllabus (Table 1). Hence, it may be concluded that the completion of the syllabus is not directly related to the opportunities of the physical learning environment and the teachers are more affected by other factors.

Table 1

\section{Connection between the physical learning environment and the completion of the syllabus}

\begin{tabular}{|c|c|c|c|c|c|c|}
\hline \multirow{2}{*}{\multicolumn{3}{|c|}{ Indicators }} & \multicolumn{3}{|c|}{$\begin{array}{l}\text { When planning the studies, do you } \\
\text { consider it important to complete the } \\
\text { content of the syllabus? }\end{array}$} & \multirow{3}{*}{$\begin{array}{r}\text { Total } \\
10\end{array}$} \\
\hline & & & Not at all & Partially & Completely & \\
\hline \multirow{6}{*}{$\begin{array}{l}\text { Does the } \\
\text { physical } \\
\text { environment } \\
\text { in your } \\
\text { school } \\
\text { restricts the } \\
\text { completion } \\
\text { of the } \\
\text { syllabus? }\end{array}$} & \multirow{2}{*}{$\begin{array}{l}\text { The physical environment is } \\
\text { unsuitable for the completion of } \\
\text { the syllabus }\end{array}$} & Count & 0 & 8 & 2 & \\
\hline & & $\%$ & $0.0 \%$ & $80.0 \%$ & $20.0 \%$ & $100.0 \%$ \\
\hline & \multirow{2}{*}{$\begin{array}{l}\text { The physical learning } \\
\text { environment does not allow to } \\
\text { fully complete the syllabus }\end{array}$} & Count & 1 & 43 & 7 & 51 \\
\hline & & $\%$ & $2.0 \%$ & $84.3 \%$ & $13.7 \%$ & $100.0 \%$ \\
\hline & \multirow{2}{*}{$\begin{array}{l}\text { The physical environment } \\
\text { allows to perform all tasks }\end{array}$} & Count & 3 & 16 & 3 & 22 \\
\hline & & $\%$ & $13.6 \%$ & $72.7 \%$ & $13.6 \%$ & $100.0 \%$ \\
\hline \multirow{2}{*}{\multicolumn{2}{|c|}{ Total }} & Count & 4 & 67 & 12 & 83 \\
\hline & & $\%$ & $4.8 \%$ & $80.7 \%$ & $14.5 \%$ & $100.0 \%$ \\
\hline
\end{tabular}

Throughout times, obtaining suitable materials for the lesson has been an important obstacle for the teachers (Alamaki, 1999). When they were asked what is the principle, they use for choosing the tasks and the materials to complete the syllabus, the teachers gave the following answers: $59 \%$ of the teachers build their lessons around the available materials (Figure 7) and $29 \%$ of the teachers attempt to obtain the necessary materials for the planned lessons. This clearly indicates the schools have great problems with providing the supplies of teaching aids and materials. The materials available in schools largely depend on the initiative of the teachers themselves to find the materials for little or no money.

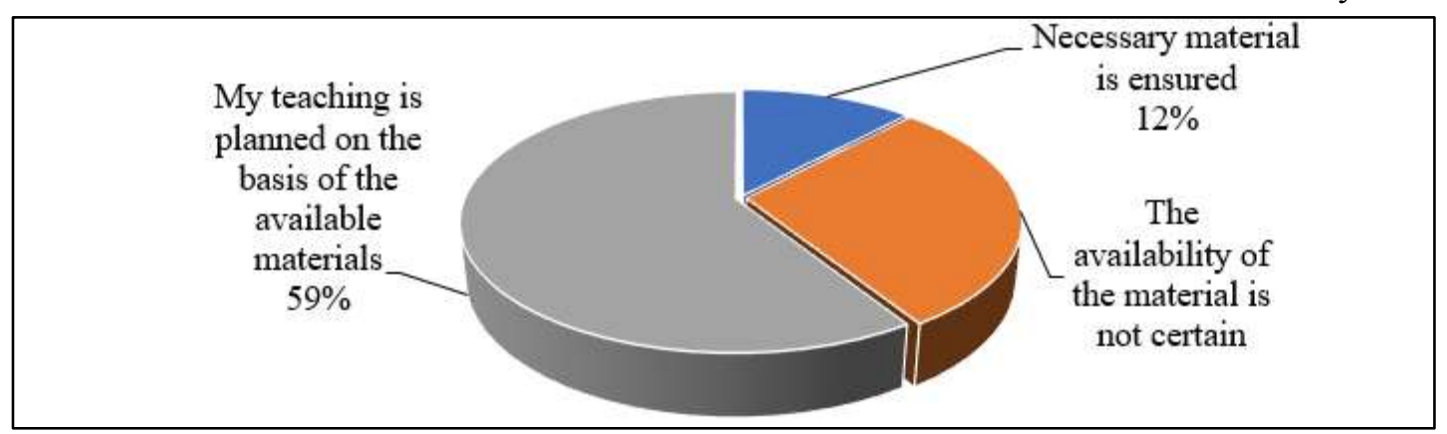

Figure 7. Obtaining materials. 
Hence, the selection of materials in schools is neither wide nor of high quality. Unvaried materials, however, considerably inhibit the choice and extent of different types of tasks and does not promote the completion of the learning objectives of the syllabus. Only $12 \%$ of the teachers can plan their work in a way that it is not inhibited by lack of materials.

\section{Conclusions}

There are many factors which influence the completion of the syllabus and conduction of the studies, which is why the syllabus can never be fully realised. Besides, the planned syllabus and the received syllabus overlap only partially - this was also revealed by a study, which indicated that more than half of the teachers completes the syllabus of crafts only partially. The statement that teachers carry out the studies based on their previous experience and knowledge and attempt to adjust the syllabus according to their own principles was also confirmed. Although over $90 \%$ of the studied crafts teachers had got acquainted with the valid syllabus, they admit that the syllabus is overloaded and too complex, which is an important reason why teachers complete the syllabus only partially. The solution would be the simplification of the syllabus both content and language wise, and publishing a study book as an additional material, which would describe and give guidelines for carrying out the lessons of the subject.

The different capability and learning motivation of the students also plays an important role in conducting the studies. Although crafts lessons are currently relatively popular at schools, the interest of the students must be preserved. The structure of the syllabus of crafts is broad-based and contains great differentiation opportunities. This opportunity is actively used by the teachers, since $80 \%$ of them differentiates the studies. Teachers also find it important to boost the intrinsic motivation of students and to support the creation of the state of flow. To do this, teachers consider, if possible, the different interests of the students when carrying out the learning activities.

To carry out practical activities, teachers need both the physical learning environment as well as the means for teaching. Although the condition of the workshops in schools has improved over the years, it has not caught up with the development of the syllabus in schools. The deficiency of the materials (wood, metal, plastic, etc.) necessary for the conduction of practical activities is also a hindering factor which inhibits the completion of the planned topics and tasks. Despite that, teachers are capable of carrying out the planned activities under poorer circumstances, overcoming the limits set by the existing physical learning environment.

\section{Bibliography}

1. Alamaki A. (1999). Technology Education in the Finnish Primary Schools. Journal of Technology Education, 11(1). Retrieved from: https://files.eric.ed.gov/fulltext/EJ592635.pdf

2. Borg K. (2006). What is sloyd? A question of legitimacy and identity. Journal of Research in Teacher Education, 2(3), 34-51.

3. Brophy J. (2010). Motivating students to learn. British Journal of Educational Technology, 41(6), E160-E164.

4. Cohen L., Manion L., Morrison K. (2007). Research Methods in Education (6th ed.). London, New York: Taylor and Francis e-Library. Retrieved from:

https://islmblogblog.files.wordpress.com/2016/05/rme-edu-helpline-blogspot-com.pdf

5. Craft teachers' data in the 2016-17. (2017). Tallinn: Eesti Hariduse Infosusteem.

6. Csikszentmihalyi M. (1993). The evolving self: A psychology for the third millennium. New York: HarperCollins.

7. Csikszentmihalyi M. (1997). Intrinsic motivation and effective teaching: A flow analysis. In J. Bess (Ed.), Teaching well and liking it: Motivating faculty to teach effectively. Baltimore: The Johns Hopkins Press, 72-89.

8. Csikszentmihalyi M., Rathunde K., Whalen S. (1993). Talented teenagers: The roots of success and failure. Cambridge, UK: Cambridge University Press.

9. Deci E.L., Ryan R.M. (1985). Intrinsic motivation and self-determination in human behavior. New York: Plenum Press.

10. Deci E.L., Ryan R.M. (Eds.). (2002). Handbook of self-determination research. Rochester, NY: University of Rochester Press. 
11. Hargreaves A. (2003). Teaching in the knowledge society: Education in the age of insecurity. New York, London: Teachers College Press.

12. Kelly A.V. (2004). The Curriculum theory and practice. (5 $5^{\text {th }}$ ed.). London: SAGE Publications. Retrieved from: http://www.aglow.edu.pk/documents/the-curriculum_theory-practice-5thedition_20042.pdf

13. Kikkull A. (2016). Didaktilised ja organisatoorsed tingimused opilaste teadmiste praktikasse rakendamise tohustamiseks tooopetuse ja reaalainete loimingu kaudu pohikoolis (Didactic and organizational conditions for forming students' applicability of knowledge through integrating craft and sciences in compulsory school). Doctoral Thesis. Tallinn: Tallinna Ulikool. (in Estonian)

14. Kikkull A. (2018). Didactic Principles in Estonian Craft and their Function in Interdisciplinary Integration. In V. Dislere (Ed.), The Proceedings of the International Scientific Conference Rural Environment. Education. Personality (REEP), 11. Jelgava: LLU TF, 288-295. Retrieved from: http://1lufb.1lu.lv/conference/REEP/2018/Latvia_REEP_2018_proceedings_ISSN2255808X.pdf\# page $=289 \&$ zoom $=100,0,116$

15. National curriculum for basic schools. (2002). Tallinn: Ministry of Education and Research.

16. National curriculum for basic schools. (2014). Tallinn: Ministry of Education and Research. Retrieved from:

https://www.hm.ee/sites/default/files/est_basic_school_nat_cur_2014_general_part_1.pdf

17. Parikka M., Rasinen A. (2009). Teknologiakasvatus tutkimuskohteena. (Technology Education as a research object). Jyvaskyla, Finland: Jyvaskylan yliopistopaino. (in Finnish)

18. Pridane A. (2017). The Study on Competence - Based Curriculum Implementation in the Subject Home Economics and Technologies. In V. Dislere (Ed.), The Proceedings of the International Scientific Conference Rural Environment. Education. Personality (REEP), 10. Jelgava: LLU TF, 376-384. Retrieved from http://llufb.llu.lv/conference/REEP/2017/Latvia-Univ-Agricult-REEP2017 proceedings.pdf\#page $=377 \&$ zoom $=100,0,97$

19. Riismaa A. (2017). Tehnoloogiaopetuse tookodade materiaal-tehnilise baasi moju oppekava taitmisele parnu linna ja maakonna koolide naitel (The effect of material-technical base of technology education classrooms at fulfilling the national curriculum as an example of the schools of Parnu and Parnu county). Magister Thesis. Tallinna Ulikool: Tallinn. Retrieved from https://drive.google.com/file/d/1wx618D40UFuNxr-uYp4m8D-emYKw723W/view (in Estonian)

20. Ritz J.M., Moye J.J. (2011). Using contextualized Engineering and Technology Education to Increase Student Motivation in the Core Academic. In M. Barak, M. Hacker (Eds.), Fostering Human Development Through Engineering and Technology Education. Reviewing the Past Twenty Years. Rotterdam, the Netherlands: Sense Publishers, 131-151.

21. Schwartz M. (2006). For whom do we write the curriculum? Journal of Curriculum Studies $38(4), 449-457$.

22. Soobik M. (2013). Physical Learning Environment and its Suitability to the Objectives of Technology Education. Journal of Technology Education, 25(1), 20-33.

23. Subject field syllabi, basic school. (2014). Subject field: Technology. Tallinn: Ministry of Education and Research. Retrieved from http://oppekava.innove.ee/subject-field-syllabuses/

24. Turner J.C., Meyer D.K., Cox K.E., Logan C., DiCintio M., Thomas C.T. (1998). Creating contexts for involvement in mathematics. Journal of Educational Psychology, 90(4), 730-745.

25. Viirpalu P., Krull E., Mikser R. (2014). Investigating Estonian Teachers Expectations for the General Education Curriculum. Journal of Teacher Education for Sustainability, 16(2), 54-70. Retrieved from-https://content.sciendo.com/view/journals/jtes/16/2/article-p54.xml

26. Wilson N., McLean S. (1994). Questionnaire Design: A Practical Introduction. Newtown Abbey: University of Ulster Press. 